\title{
The law and policy of government access to private sector data ('B2G data sharing')
}

\section{Heiko Richter}

\section{A. Issue}

How can policymakers and legislatures improve the state's access to data held by private undertakings? Data are the basis for harvesting new insights, creating knowledge and providing innovative goods and services. Therefore, access to data can benefit the public welfare and serve society at large. Asking to what extent and by what means the state should be entitled to access private undertakings' datasets on behalf of the public interest lies at the core of the general discourse on the state's role in a data-based society. This chapter contributes to this debate and aims to advance regulatory approaches to data access.

The creation of rights for the state to access data held by private companies has been increasingly discussed in recent years. While the OECD has focused on fostering voluntary public-private cooperation, ${ }^{1}$ France has introduced the notion of 'public interest data', which it implemented in its Loi Lemaire in 2016 after a comprehensive stakeholder consultation. ${ }^{2}$ The EU followed the French initiative and became active in the field of B2G

1 For the OECD policies see Charlotte van Ooijen, Barbara Ubaldi, and Benjamin Welby, 'A data-driven public sector: Enabling the strategic use of data for productive, inclusive and trustworthy governance' (2019) OECD Working Papers on Public Governance No. 33 <www.oecd-ilibrary.org/docserver/09ab162c-en.pdf?expires= 1605081692\&id=id\&accname=guest\&checksum =54003ECF6F8210640E34FE63267 EB459> accessed 31 August 2020; Alberto Alemanno, 'Big Data for Good: Unlocking Privately-Held Data to the Benefit of the Many' (2018) 9 European Journal of Risk Regulation 183, 187.

2 See provisions on data of general interest ('données d'intérêt général') under Arts 1724 Loi $n^{\circ}$ 2016-1321 pour une République numérique of 7 October 2016 ('Loi Lemaire'). 
data sharing in $2017 .{ }^{3}$ After delivering its 'data package' of $2018,{ }^{4}$ the Commission appointed an expert group on B2G data sharing, which issued its final report in February 2020. The expert group recommended that the Commission should further 'explore the creation of a regulatory framework enabling the development of fast, responsible and sustainable B2G data sharing for public-interest purposes'. ${ }^{5}$ In Germany, in contrast, the debate is just getting started. ${ }^{6}$ The country's Data Ethics Commission has considered the creation of an obligation to grant access to a defined subset of data for specific public authorities or purposes of general interest. ${ }^{7}$ Moreover, the federal government's data strategy aims to better exploit the potential of using data to improve policy implementation and evaluation and to fulfil the tasks of state institutions in a more efficient and citizenfriendly way. ${ }^{8}$ In any case, these developments underline the increasing initiative to address government access to data held by private undertak-

3 European Commission, 'DG CONNECT Draft report: 26 June 2017 workshop on access to privately-held data for public bodies' (European Commission 2017) $<$ https://ec.europa.eu/information_society/newsroom/image/document/2017-28/fin al_-_report_from_reverse_psi_workshop_B7FA94EE-FA15-1929-8BBA2754D0D2F BE9_45916.pdf $>$ accessed 31 August 2020.

4 See Communication from the Commission of 25 April 2018 to the European Parliament, the Council, the European Economic and Social Committee and the Committee of the Regions - 'Towards a common European data space' $\operatorname{COM}(2018) 232$ final, 1-2.

5 European Commission, 'Towards a European strategy on business-to-government data sharing for public interest - Final report prepared by the High-Level Expert Group on Business-to-Government Data Sharing' (2020) $28<$ www.euractiv.com/w p-content/uploads/sites/2/2020/02/B2GDataSharingExpertGroupReport-1.pdf> accessed 31 August 2020.

6 Only briefly dealing with the topic the German Data Ethics Commission, 'Report of the Data Ethics Commission of the Federal Government (2019) 154 <www.bmjv .de/SharedDocs/Downloads/DE/Themen/Fokusthemen/Gutachten_DEK_EN_lang. pdf?_blob=publicationFile $\& v=3>$ accessed 31 August 2020. See also Bundesministerium für Wirtschaft und Energie (German Federal Ministry for Economic Affairs and Energy), 'Ein neuer Wettbewerbsrahmen für die Digitalwirtschaft: Bericht der Kommission Wettbewerbsrecht 4.0' (2019) 46-47 <www.bmwi.de/Redaktion/DE/P ublikationen/Wirtschaft/bericht-der-kommission-wettbewerbsrecht-4-0.pdf?_blob $=$ publicationFile $\& v=12>$ accessed 31 August 2020, but only on companies which are linked to the fulfilment of public tasks.

7 See Data Ethics Commission (n. 6) 154.

8 Bundesregierung, 'Eckpunkte einer Datenstrategie der Bundesregierung' (2019) <www.bundesregierung.de/resource/blob/975226/1693626/60b196d5861f71cdefb9 e254f5382a62/2019-11-18-pdf-datenstrategie-data.pdf $>$ accessed 30 April 2020. 
ings, including mandatory rules which regulate such access in the EU and the Member States.

However, the research on systematic approaches to laws and policies is underdeveloped. ${ }^{9}$ This chapter will close this gap by inquiring into the justification, design and implementation of rules which mandate the state's access to data held by private undertakings (i.e. 'government access' or 'B2G data sharing' ${ }^{10}$ ). For this purpose, Section B outlines the broader context and the objectives of government access. Section $\mathrm{C}$ delineates the research focus, which lies on mandatory access rules that address private undertakings without any public link as well as on horizontal issues with regard to non-personal data. Section D elaborates on the key questions such access rules should address. Section E develops principles for designing and implementing access rules. Section F reflects on the opportunities and limitations of implementing horizontal B2G access frameworks. Finally, Section G highlights the implications for concrete legislative reforms, and Section $\mathrm{H}$ concludes this chapter.

\section{B. Context and objectives of government access}

\section{Development context}

To understand the objectives of government access to privately held data, it is helpful to grasp the broader technological and societal context of the debate. Some relevant developments highlight the growing significance of data: the disruptive technological innovations which led to the 'data revolution' ${ }^{11}$ mark the starting point. New technology has enabled the advent of a decentralised, market-driven system of data collection that is unprecedented in scope. Moreover, cloud and high-performance computing has fa-

9 But see for research on specific aspects or fields of application Teresa Scassa, 'Sharing Data in the Platform Economy: A Public Interest Argument For Access to Platform Data' (2017) 50 UBC Law Review 1017; Niva Elkin-Koren and Michal Gal, 'The Chilling Effect of Governance-by-Data on Data Markets' (2019) 86 University of Chicago Law Review 403; Alfred Früh, 'Datenzugangsrechte: Rechtsrahmen für einen neuen Interessenausgleich in der Datenwirtschaft' (2018) sic! Zeitschrift für Immaterialgüter-, Informations- und Wettbewerbsrecht 521; rather general Alemanno (n. 1).

10 The term 'sharing' might be misleading as it connotes voluntary data exchange. Yet in practice it is often used as a synonym.

11 For the background Robert Kitchin, The Data Revolution (Sage 2014). 
cilitated new techniques of data evaluation ${ }^{12}$ while new means of data transmission have allowed for the immediate, worldwide transfer of large data streams.

These technological advancements and the corresponding cost reductions have enabled many private companies to collect data in vastly greater amounts, ${ }^{13}$ of better quality and on new issues and circumstances. Airbnb's housing occupancy data ${ }^{14}$ and Uber's data on trips ${ }^{15}$ are prime examples. The public sector has benefited from this development as well however, the scope of the state's legitimate, data-related activities is strictly disciplined in democracies which abide by the rule of law. As a consequence, the flourishing of data-driven markets has shifted the balance: public sector data stocks are no longer larger and better than those of private companies. In fact, the opposite is often the case. ${ }^{16}$ Big private platforms collect and hold more data than many governments. ${ }^{17}$ Therefore, states have become interested in accessing such privately held data to improve decision-making and public services.

The shift of balance from public to private has two implications on which this chapter will not elaborate, but which set the broader societal context and should therefore be borne in mind when discussing the policy and law of B2G data sharing. First, considering that 'knowledge is power', a data shift implies a shift of power. ${ }^{18}$ In this light, government access to private data could reconfigure 'power imbalances'. Such power-related motives are often not made explicit, ${ }^{19}$ even though they considerably affect the policy debate on B2G data sharing behind the scenes. Second, ethical considerations and perceptions of justice play an important role. Data-driven innovation raises general ethical concerns. When it comes to B2G data

12 For example, big data analytics, machine learning etc.

13 Bertin Martens and Néstor Duch-Brown, 'The economics of Business-to-Government data sharing' (2020) JRC Digital Economy Working Paper 2020-04, 5 $<$ https://papers.ssrn.com/sol3/papers.cfm?abstract_id=3540122 $>$ accessed 31 August 2020.

14 See in detail Scassa (n. 9).

15 See $<$ https://movement.uber.com $>$ accessed 30 April 2020.

16 See Früh (n. 9) 524.

17 Jennifer Shkabatur, 'The Global Commons of Data' (2019) 22 Stanford Technology Law Review 354, 357.

18 For details on this conceptualisation Heiko Richter, 'The Power Paradigm in Private Law' in Mor Bakhoum and others (eds), Personal Data in Competition, Consumer Protection and Intellectual Property Law (Springer 2018) 527.

19 An illustrative example is the wording of Alemanno (n. 1) 185: 'private data remains the prerogative of a few big corporations who jealously guard it'. 
sharing in particular, there continues to be widespread scepticism in the aftermath of the PRISM scandal. Edward Snowden revealed that an extensive, in-depth surveillance programme was being facilitated by government access to vast amounts of personal live communication and information which had been stored by private operators. ${ }^{20}$ Policy and legislation can address such concerns e.g. by discussing restrictions to access that would protect privacy. ${ }^{21}$ Yet the societal sensitivity of the debate on government access to data must always be taken into account, even if the focus of this chapter is on non-personal data. ${ }^{22}$

Concrete trends regarding data access emerge within this broader societal context. There is a clear political belief on the EU level in fostering data sharing between various actors in order to realise the full economic and societal value of data. ${ }^{23}$ However, this is understood to go along with the increased practice of selective sharing. While 'open data', i.e. data for everyone for unrestricted purposes, was an ideal of the 2010s, the 2020s will reveal considerably more nuanced approaches to data sharing unlocked by new technologies. ${ }^{24}$ Furthermore, the emphasis has begun to shift away from data quantity towards data quality. The recent recast PSI Directive ${ }^{25}$ reflects this insofar as it defines high-value data sets and addresses real-time data and further quality characteristics in detail. Finally, combining the quality aspect with the fact that technology continues to become more

20 See Adam Florek, 'The Problems with PRISM: How A Modern Definition of Privacy Necessarily Protects Privacy Interests in Digital Communications' (2014) 30 John Marshall, Information, Technology \& Privacy Law 571. In particular, the U.S. government could access data from Google, YouTube, Facebook, Microsoft, Skype, PalTalk, AOL, Yahoo, Apple etc.; see James Ball and Dominic Rushe, 'NSA Prism program taps in to user data of Apple, Google and others' (The Guardian, 6 June 2013) <www.theguardian.com/world/2013/jun/06/us-tech-giants-nsa-data $>$ accessed 31 August 2020.

21 See proposals of Data Ethics Commission (n. 6).

22 See section C.V. below.

23 See Communication from the Commission of 19 February 2020 to the European Parliament, the Council, the European Economic and Social Committee and the Committee of Regions - A European strategy for data, $\operatorname{COM}(2020) 66$ final.

24 Teresa Scassa, 'Keynote Address from Go Open Data 2019 Conference' (6 May 2019) <www.teresascassa.ca/index.php?option $=$ com_k2\&view=item\&id=307:keyn ote-address-from-go-open-data-2019-conference> accessed 31 August 2020. Therefore, the idea of data commons is not restricted to its origin of research data; see Shkabatur (n. 17) 384.

25 Parliament and Council Directive (EU) 2019/1024/EU of the European Parliament and the Council of 20 June 2019 on open data and the re-use of public sector information [2019] OJ L172/56. 
complex, higher investments are needed. This has implications for financing and compensation regimes. ${ }^{26}$

\section{Objectives of government access}

Making more and better ${ }^{27}$ privately held data accessible to the state can serve various purposes. In any case, data access is a means to an end, its overall goal being social welfare enhancement. ${ }^{28}$ But what exactly is the novelty of this discussion? One could argue that states' rights to access the information of private companies constitute a longstanding practice, e.g. when thinking about companies' taxation duties, business reporting obligations or legal compliance. However, the game-changing element lies in the new types and improved quality of datasets and the new analytical methods to harvest insights. In addition, new means of data transmission and cloud computing allow real-time data sharing and analysis and enable public authorities to 'tap into the data flow' of private companies. ${ }^{29}$

This technological advancement opens up numerous opportunities for the public sector to ultimately create social benefits and foster the common good. ${ }^{30}$ Data access can increase the efficiency of the public sector, e.g. by reducing costs and effort if some data do not have to be collected again. ${ }^{31}$ Moreover, data access can improve the internal performance of the administration on the basis of the accessed data. ${ }^{32}$ Data access can also enable public sector bodies to innovate their policies and services, which is in line with the Commission's goal of unleashing the potential of data management and data-driven innovation. ${ }^{33}$

26 See sections D.VI., F.IV. and G.III. below.

27 As regards data quality, see van Ooijen, Ubaldi and Welby (n. 1) 30.

28 See Martens and Duch-Brown (n. 13) 9, who also point to methodological problems of determining and quantifying welfare gains.

29 Bram Klievink and others, 'Regulatory Compliance and Over-Compliant Information Sharing - Changes in the B2G Landscape' in Peter Parycek and others (eds), Electronic Government (Springer 2018) 249, 252.

30 See Martens and Duch-Brown (n. 13) 7.

31 European Commission (n. 5) 17; Martens and Duch-Brown (n. 13) 5.

32 See van Ooijen, Ubaldi and Welby (n. 1) 22-24.

33 European Commission Communication $\operatorname{COM}(2018) 232$ final (n. 4) 1-3; European Commission (n. 5) 17; Stefaan G. Verhulst and Andrew Young, 'How the Data That Internet Companies Collect Can Be Used for the Public Good' (23 January 2018) Harvard Business Review <https://hbr.org/2018/01/how-the-data-that-i 
For which purposes can the state legitimately use the data of private undertakings? One can identify three rather abstract categories. First, the data can deliver insights that guide decision-making and the design and evaluation of public policies. ${ }^{34} \mathrm{~A}$ better basis of information may therefore improve policies ex ante and ex post. ${ }^{35}$ Second, data can be directly or indirectly used in providing public services to citizens. ${ }^{36}$ Such better public service delivery' addresses both the development and the performance ${ }^{37}$ of the service. Third, the promotion of economic development and competition may be seen as another category. ${ }^{38}$ This category is somewhat debatable, however, as it presumes that the state passes on the data to third parties. It will be seen that this case lies at the borderline of $\mathrm{B} 2 \mathrm{G}$ sharing because it also covers the re-use of data which the state has obtained from private undertakings on the basis of mandatory access rules. ${ }^{39}$

\section{Public task and examples}

The above-mentioned categories of general objectives crosscut many concrete purposes and areas of application for government access to privately held data. The public task is the starting point for determining such purposes. Government access to data must serve a public task which reflects

nternet-companies-collect-can-be-used-for-the-public-good> accessed 31 August 2020.

34 See van Ooijen, Ubaldi and Welby (n. 1) 18-20; Martens and Duch-Brown (n. 13) 5; European Commission (n. 5) 17; European Commission Communication $\operatorname{COM}(2018) 232$ final (n. 4) 12.

35 Laurent Cytermann and others, Rapport relatif aux données d'intérêt général (2015) $2<$ www.economie.gouv.fr/files/files/PDF/DIG-Rapport-final2015-09.pdf> accessed 31 August 2020; Alemanno (n. 1) on the role to prove or falsify the effectiveness of regulatory measures.

36 See Martens and Duch-Brown (n. 13) 5. For the distinction and convergence of the concept 'consumer' vs. 'citizen' Sofia Ranchordás, 'Citizens as Consumers in the Data Economy: The Case of Smart Cities' (2018) Journal of European Consumer and Market Law 154.

37 See van Ooijen, Ubaldi and Welby (n. 1) 20-22; European Commission Communication COM (2018) 232 final (n. 4) 12; European Commission (n. 5) 17. See on personalisation of the services Ricard Munné, 'Big Data in the Public Sector' in Jose M. Cavanillas, Edward Curry and Wolgang Wahlster (eds), New Horizons for a Data-Driven Economy (Springer 2016) 195.

38 Cytermann and others (n. 35) 2.

39 See sections E.III. and G.IV. below. 
the public interest. ${ }^{40}$ The Member States are free to define the public interest and designate public tasks accordingly. ${ }^{41}$ Thus, the public task is a dynamic concept. At the same time, technology determines possible tasks and the means of their fulfilment. Government access to data can therefore serve to improve the fulfilment of existing public tasks - e.g. protecting public health by gaining insights into the spread of pandemics on the basis of phone operators' movement data or improving urban housing planning by using rental data from rental platforms. ${ }^{42}$ But beyond such improvements, the state can take on completely new public tasks. This can include the production of innovative outputs based on the data. ${ }^{43}$ One emerging field regards strengthening state oversight of scoring algorithms. ${ }^{44}$

There are a countless number of examples of how the state may optimise the performance of existing tasks or fulfil new tasks on the basis of privately held datasets. This concerns e.g. environmental protection, official statistics, public health, natural hazard and disaster management, public safety, urban planning, transport, energy supply, smart cities in general, consumer protection, research and market monitoring. ${ }^{45}$ Yet there is no particular order or taxonomy when it comes to public tasks and data access. The reason for this conceptual shortcoming lies in the multiple purposes which a single dataset can serve. Also, policy discussions have

40 On the different concepts of the 'public tasks' across the EU see Heiko Richter, 'Open Science and Public Sector Information' (2018) 9 Journal of Intellectual Property, Information Technology and E-Commerce Law 51, 65-66.

41 See on the problem of definition European Commission (n. 5) 17; in the EU context, the CJEU jurisprudence on 'determining services of general public interest' can give some guidance: see Case T-289/03 BUPA and Others v. Commission EU:T:2008:29, paras 165-70; Case T-17/02 Olsen v. Commission EU:T:2005:218, para. 216; Case T-106/95 FFSA and Others v. Commission EU:T:1997:23, para. 99; Case 127/73 BRT v. SABAM EU:C:1974:25, para. 23.

42 See Früh (n. 9) 526 on Airbnb.

43 See Martens and Duch-Brown (n. 13) 5.

44 In this direction Shkabatur (n. 17) 360.

45 For examples see European Commission Communication COM (2018) 232 final (n. 4) 14; Communication from the Commission of 10 January 2010 to the European Parliament, the Council, the European Economic and Social Committee and the Committee of the Regions - 'Building a European data economy' $\operatorname{COM}(2017) 9$ final, 14; European Commission (n. 5) 19; Früh (n. 9) 527; Alemanno (n. 1) 184; Shkabatur (n. 17) 359; Data Ethics Commission (n. 6) 154; Bundesministerium für Wirtschaft und Energie (n. 6) 46. 
evolved on the basis of use cases ${ }^{46}$ in various areas. The evidence at hand is therefore anecdotal and not empirically reliable.

\section{Research focuses}

\section{Overview}

There are many potential ways for policymakers to improve governmental access to privately held data. However, 'B2G data sharing' is not clearly defined - the discourse is still at an early stage. This chapter does not aim to put forward a universal definition, but it must at least determine its focus by delineating the scope of research. As will be shown in the following, this chapter focuses on mandatory access rules which concern data held by private undertakings without public links. Furthermore, the chapter concentrates on overarching aspects and addresses neither sector-specific particularities nor personal data.

\section{Mandatory access rules}

Mandatory access rules - meaning binding laws, in contrast to non-binding guidelines $s^{47}$ - predominantly concern statutory access rules. Yet one should keep in mind that mandatory access rules lie at one extreme of a spectrum. There are other, less interventionist instruments to foster data access (e.g. incentives, reduction of transaction costs or soft law approaches). ${ }^{48}$ Mandatory access rules restrict the freedom of enterprises vis-à-vis the state. Therefore, they need substantive justification in the face of fundamental rights. As a consequence, the legislature has to master challenges of a different kind compared to the much-discussed issue of data access be-

46 Illustrative examples in European Commission (n. 3) 5; European Commission Communication COM (2018)232 final (n. 4) 12; Shkabatur (n. 17) 361; see also case studies in European Commission (n. 5) Annex II.

47 The Commission outlined such principles in its Communication COM (2018) 232 final (n. 4) 12-14 and revised them in European Commission (n. 5) 79-86. See also European Commission Staff Working Document, 'Guidance on sharing private sector data in the European data economy' SWD(2018) 125 final.

48 See Shkabatur (n. 17) 402-404 on 'carrots'; Martens and Duch-Brown (n. 13) 21. 
tween private parties. ${ }^{49}$ Mandatory access rules must be seen as a last resort within the range of measures to foster data access.

With this in mind, the EU has started to consider mandated sharing (alongside other instruments ${ }^{50}$ ) as a potential building block for a new regulatory framework. ${ }^{51}$ But what is the relevance and value of focusing on mandatory access rules from a substantive point of view? The move towards mandatory rules aims to compensate for the actual deficiency of data shared on a voluntary basis despite its vast economic and societal potential. ${ }^{52}$ In fact, the B2G data sharing debate originates from 'data philanthropy' initiatives in the humanitarian aid sector. ${ }^{53}$ Voluntary sharing increasingly takes place. Accordingly, contractual agreements are the main legal tool. ${ }^{54}$ There are various examples of 'data collaboratives', ${ }^{55}$ among others in the transport ${ }^{56}$ and utility ${ }^{57}$ sectors and regarding mobile phone data. ${ }^{58}$ However, so far cooperation appears sector- and context-dependent, selective, sporadic and rather experimental, and markets for data sharing are said to be nascent and small. ${ }^{59}$ Reports on voluntary B2G data sharing between the state and private undertakings are generally pessimistic, forecasting a slow development and expressing doubt that pilot projects will

49 See the European Commission Communications $\operatorname{COM}(2017) 9$ final (n. 45) and $\operatorname{COM}(2018) 232$ final (n. 4). In detail Josef Drexl, 'Designing Competitive Markets for Industrial Data - Between Propertization and Access' (2017) 8 Journal of Intellectual Property, Information Technology and E-Commerce Law 257; Heiko Richter and Peter Slowinski 'The Data Sharing Economy: On the emergence of New Intermediaries' (2019) 50 International Review of Intellectual Property and Competition Law 4.

50 For the wide range of measures to be considered see European Commission (n. 5).

51 European Commission (n. 5) 75; Martens and Duch-Brown (n. 13) 21.

52 See Martens and Duch-Brown (n. 13) 11.

53 See UN Global Pulse <www.unglobalpulse.org/mapping-corporate-data-sharing > accessed 31 August 2020. See also Früh (n. 9) 529; Alemanno (n. 1) 186.

54 See European Commission (n. 5) 31.

55 See Alemanno (n. 1) 186; for a taxonomy see Verhulst and Young (n. 33).

56 See e.g. iSHARE Data Sharing Scheme in the Dutch logistics sector $<$ www.ishare works.org $>$ accessed 31 August 2020.

57 See Shkabatur (n. 17) 392 on the 'California Data Collaborative' for water management, <http://californiadatacollaborative.org/> accessed 31 August 2020.

58 See Früh (n. 9) 529; according to Ramón Muñoz and Pablo Cantó, 'El INE arranca el rastreo de millones de móviles pero hay formas de esquivarlo' (El País, 17 November 2019) < https:/elpais.com/economia/2019/11/17/actualidad/157400844 5_307680.html $>$ the Spanish National Institute of Statistics will pay half a million EUR to Telefónica, Vodafone and Orange.

59 Martens and Duch-Brown (n. 13) 11; Shkabatur (n. 17) 398; Alemanno (n. 1) 187. 
evolve into sustainable initiatives. ${ }^{60}$ However, the lack of empirical evidence forbids a generalisable conclusion. So far the B2G discussion has tended to follow anecdotal evidence and implicit assumptions. ${ }^{61}$

Still, it appears sensible to follow some theoretical, incentive-related arguments which appear to support the call for mandatory access. Their core premise is that the private party must somehow benefit from data sharing if it voluntarily decides to participate. In contrast, the abstinence from voluntary data sharing that we observe in reality can be explained by various disincentives: the cost associated with the processing and provision of the data; a loss of control over the data and especially the risk of data leaks to unauthorised third parties; the fear of infringing rights, especially in the areas of personal data, trade secrets, IP and competition law; strategic disadvantages in competition; and the concern that government might use the data against the company, e.g. by enacting market regulation or taking enforcement measures. ${ }^{62}$

Therefore, when considering mandatory access rules, one may not overlook specific market developments and their respective disincentives to share data. There may be public interest reasons to intervene, but mandatory access regulation remains the ultima ratio from a market standpoint. In any case, access rules have to account for their possible effects on voluntary data provision and the incentives for affected actors. This implies that access rules must also contain the safeguards that are necessary to keep mandatory rules from causing dysfunction.

\section{Data of private undertakings without a public link}

The focus on private undertakings concerns commercial entities that are not individuals. These entities have to be entirely private, meaning that they

60 European Commission (n. 5) 32; Martens and Duch-Brown (n. 13) 11; Alemanno (n. 1) 187.

61 Martens and Duch-Brown (n. 13) 5, 12, 13. Früh (n. 9) 529 says that private individuals are 'often' willing to disclose data on a voluntary basis, however, it does not appear clear what 'often' means from an empirical point of view. See Bertrand Pailhès, 'How to define and regulate "data of general interest"? (2018) 1(2) Enjeux numériques <www.annales.org/enjeux-numeriques/2018/resumes/jui n/09-en-resum-FR-AN-juin-2018.html> accessed 31 August 2020, who assumes that development does not progress without legal intervention.

62 See Martens and Duch-Brown (n. 13) 19; Alemanno (n. 1) 185; Früh (n. 9) 524, 528; European Commission (n. 5) 27. 
are not at all linked to a public person. ${ }^{63}$ This not only excludes public undertakings ${ }^{64}$ but also privately controlled undertakings linked to public authorities on the basis of their involvement in the performance of public tasks ${ }^{65}$ or their public financing. France addressed such 'para publics' in its legislation by adding a mandatory access clause to the rules on the award of service concessions in 2016. ${ }^{66}$ The EU also discussed the introduction of such rules when revising the PSI Directive, but ended up merely recommending the Member States to enact such legislation. ${ }^{67}$ In Germany, the Kommission Wettbewerbsrecht 4.0 suggested that private companies entrusted with tasks of general interest should be obliged to make data generated in the course of this activity available to public authorities. ${ }^{68}$ Such data should not only be made available to the public sector (for public purposes) but also to market participants. ${ }^{69}$ The German legislature, however, has not taken up this issue yet.

The data of private undertakings with public links are left out because they have distinct functional features and pose different legal challenges. If there is already a link to the state, intervention seems less critical because its reason lies precisely in the planned involvement of the private undertaking in the fulfilment of public tasks. The undertaking's obligations are then coupled with privileges. There is usually a contractual relationship between the state and the private undertaking in such cases. Respective reform discussions therefore revolve around the effectiveness of agreements and the methodological challenge lies in getting evidence about the data provision as set out in these agreements. An important reason why the law imposes mandatory contract law is to correct government failure due to

63 See European Commission (n. 5) 35.

64 See Art. 2(1) PSI Directive (n. 25): “"public sector body” means the State, regional or local authorities, bodies governed by public law or associations formed by one or more such authorities or one or more such bodies governed by public law'.

65 See European Commission (n. 5) 20, particularly referring to 'data-sharing obligations as part of subcontracted services' and respective examples.

66 According to Art. L-3131 Code de la commande publique, the state should receive data from the concessionaire which 'have been collected or produced during the operation of the public service covered by the contract and are essential for its fulfilment'. For background see Ralf Schnieders, 'Die neue Open-(Government)Data-Gesetzgebung in Frankreich und in Deutschland' (2018) Die Öffentliche Verwaltung 175.

67 See Recital 19 PSI Directive (n. 25); the basic idea is not at all new; see already European Commission, 'Amended proposal for a Council Directive on the Legal Protection of Databases' COM(93) 464 final, Art. 11(2)(b), 7.

68 Bundesministerium für Wirtschaft und Energie (n. 6) 46.

69 Ibid. 47. 
asymmetries: when it comes to awarding contracts that include data clauses, municipalities often appear inferior to the private sector in terms of negotiating power and skills. ${ }^{70}$

\section{Horizontal aspects}

Another focus of this chapter lies on overarching considerations for regulation. Therefore, sector-specific peculiarities are not addressed. This may come as a surprise since the B2G data-sharing debate has so far supported the sectoral (vertical) advancement of rules ${ }^{71}$ instead of cross-sectoral (horizontal) regulation. In fact, sector-specific access rules already exist. From a policy point of view, there are good reasons for sector-specific advancement ${ }^{72}$ because different interests - depending on the purpose ${ }^{73}$ - and distinct competencies are involved. From a legal standpoint, access obligations may also account for different constitutional requirements that correspond with specific sectors and purposes. ${ }^{74}$ Finally, sector-specific access obligations may better account for the practical circumstances of specific sectors: it may be easier to define concrete objectives and what data they require; furthermore, formats, compensation and technical interoperability differ across sectors. ${ }^{75}$

This chapter, however, takes another angle. It asks which aspects are to be addressed in general, regardless of the sector. Exposing the common denominator and drawing general principles can inform the further development of sector-specific rules. At the same time, the focus on overarching aspects can inform the issue in terms of gauging the benefits of establish-

70 For detailed background, see Cytermann and others (n. 35). Regarding problems in the smart city context (Amsterdam and Hamburg) see Früh (n. 9) 529-30, where the right to sell the solutions to other cities was reserved to private partners.

71 See Data Ethics Commission (n. 6) 154; Bundesministerium für Wirtschaft und Energie (n. 6) 47.

72 See Josef Drexl, 'Neue Regeln für die Europäische Datenwirtschaft? Ein Plädoyer für einen wettbewerbspolitischen Ansatz - Teil 2' (2017) 5 Neue Zeitschrift für Kartellrecht 415, 419; Data Ethics Commission (n. 6) 154 with particular emphasis on the sectors health, mobility and energy.

73 See Drexl (n. 49) 289, who stresses that security interests of the state would require other approaches than the prevention of epidemics, environmental protection or the functioning of 'smart cities'.

74 See Data Ethics Commission (n. 6) 154.

75 Drexl (n. 72) 419; Data Ethics Commission (n. 6) 154; Pailhès (n. 61) 5. 
ing a horizontal B2G data access framework. This concrete question will be addressed later on. ${ }^{76}$

\section{Non-personal data}

Finally, this chapter does not elaborate on problems of privacy. Rather, it assumes that data access rules comply with given data protection rules. To avoid their violation, only derived, aggregated and processed data are shared in many cases. ${ }^{77}$ This focus does not ignore the immense challenge B2G data access poses for data protection law, which becomes evident e.g. in the recent debate on accessing the data of mobile phone operators to fight the spread of the Sars-CoV-2 pandemic. ${ }^{78}$ However, a thorough discussion of the data protection conformity of mandatory access rules lies beyond the scope of this paper and is reserved to further research.

\section{Key questions that access rules should address}

\section{Overview}

When thinking about the issues that mandatory access rules should address, it is helpful to ask five key questions: what for (purpose), for whom (beneficiaries), against whom (obliged parties), to what (relevant data) and how (modalities of access)?

\section{Purpose (what for?)}

The government's purpose in accessing the data (what for?) is the question to start with. The purpose reflects the public interest ${ }^{79}$ and forms the reference point for all the subsequent questions that access rules should address. This means that the conditions for access largely depend on the pur-

76 See section G. below.

77 See Martens and Duch-Brown (n. 13) 18.

78 On the controversy regarding planned legislative amendments in Germany, Thomas Rudl, 'Jens Spahn lässt Testballon steigen' (Netzpolitik.org, 23 March 2020) <https://netzpolitik.org/2020/jens-spahn-laesst-testballon-steigen/> accessed 31 August 2020.

79 See also Commission Staff Working Document SWD(2018) 125 final (n. 47) 14. 
pose that the data should serve. Usually, the purpose lies in solving a problem (e.g. optimising urban traffic) or serving a goal (e.g. fostering transparency). It therefore focuses on ends (outputs like knowledge and insights) rather than means (inputs, data). ${ }^{80}$ Moreover, the purpose is context-specific because the concept of 'public interest' is a dynamic one. ${ }^{81}$ Accordingly, access rules can address the purpose either in a specific and explicit or in a more general and implicit manner. ${ }^{82}$ The regulatory challenge is to clearly define the purpose in correspondence with the public interest and to set up a transparent process that helps to identify the concrete public interest. Practices in the Member States largely differ.

Access rules which entitle the state vis-à-vis private undertakings naturally concern fundamental rights. Therefore, such rules encroach on legal positions, especially the freedom of business and (potentially) property protection. ${ }^{83}$ While purpose limitation is an established data protection principle, ${ }^{84}$ there is no general principle of purpose limitation outside the area of personal data. Nevertheless, the principle of purpose limitation ${ }^{85}$ puts the rule of law in concrete terms - otherwise, the proportionality of concrete measures could not be assessed in relation to the legislative goal. ${ }^{86}$ Considering that the same dataset can be used for various purposes, its 'general purpose nature' stands in natural tension with the principle of purpose limitation. This problem will be further discussed when examining the relationship between access rules and re-usability. ${ }^{87}$

80 This hints to the distinct focus of Martens and Duch-Brown (n. 13), who generally tackle the supply/input side by elaborating on different measures to generally increase data sharing and respective transactions by overcoming barriers to sharing.

81 See European Commission (n. 5) 16.

82 E.g. the definition of data itself can imply the purpose of access.

83 On the relevance of fundamental rights and data access regulation see Fabian Michl, 'Datenbesitz - ein grundrechtliches Schutzgut?' (2019) Neue Juristische Wochenschrift 2729; Andreas Wiebe and Nico Schur, 'Ein Recht an industriellen Daten im verfassungsrechtlichen Spannungsverhältnis zwischen Eigentumsschutz, Wettbewerbs- und Informationsfreiheit' (2017) Zeitschrift für Urheberund Medienrecht 461.

84 See Paul M. Schwartz, 'Systematic government access to private-sector data in Germany' (2012) 2 International Data Privacy Law 289.

85 See European Commission Communication COM (2018) 232 final (n. 4) 13.

86 See Gertrude Lübbe-Wolff, 'The Principle of Proportionality in the Case-Law of the German Federal Constitutional Court' (2014) 34 Human Rights Law Journal 12.

87 See sections E.III. and G. IV. below. 


\section{Beneficiaries (for whom?)}

As a next step, the entitled actor needs to be designated as a beneficiary (for whom?). The right to access the data of private undertakings is granted to 'the state', meaning public sector bodies. This includes public authorities but excludes public undertakings. ${ }^{88}$ In any case, the principle of proportionality may require precisely specifying the entity that is authorised to access the data. As the focus lies on privileged access for the state, the state is not seen as one of many 'external stakeholders' but as an actor sui generis. Cases in which the state receives data in parallel to third parties ${ }^{89}$ are therefore not considered as government data access cases.

Besides direct access between the state and private undertakings, some cases can also be considered as government data access but in modified forms adapted to the complexity of data ecosystems. This covers scenarios of 'mandated intermediaries', where the law empowers the state to mandate private data holders to make their data directly accessible to a private intermediary so that it can analyse the data and ultimately provide processed data or insights to the state. Such scenarios occur where the state lacks the capacity to perform the data analysis itself. ${ }^{90}$ One regulatory challenge concerns how to deal with benefits that the private intermediary might gain from accessing the data. Such 'data advantages' are often a better incentive for firms to get involved than financial incentives. ${ }^{91}$ Cases of 'mandated intermediaries' are distinct from scenarios where a third party gains access to the data but then provides the data or insights to the state

88 In fact, one could theoretically think of access rules which specifically entitle public undertakings to access private undertakings' data for the purpose of fulfilling their public interest mission. However, such constellations raise mostly sector-specific challenges and concerns.

89 E.g. through private open data obligations or policies of 'data for everyone', see proposal on progressive data sharing by Viktor Mayer-Schönberger and Thomas Ramge, Das Digital - Markt, Wertschöpfung und Gerechtigkeit im Datenkapitalismus (Econ 2017) 194.

90 This scenario resembles a portability right (e.g. Art. 20 GDPR); see for the general concept Inge Graef, Martin Husovec and Nadezhda Purtova, 'Data Portability and Data Control: Lessons for an Emerging Concept in EU Law' (2018) 19 German Law Journal 1359; Drexl (n. 49) 286.

91 This is for example reflected in the new rules on de facto exclusivity on data in public private partnerships according to Recital 50 and Art. 12(4) PSI Directive (n. 25); see also Richter and Slowinski (n. 49) 16, on sharing platforms. 
and private providers. ${ }^{92}$ An example is 'Copenhagen City Data Exchange', a data trading platform set up in cooperation with Hitachi. ${ }^{93}$

Another distinct scenario is one in which the state directly receives datasets from the private data holder but then passes them on ${ }^{94}$ to third parties (which, however, cannot claim direct access against the original data holder). This is only to be considered a case of B2G data sharing (the state being the 'mandated intermediary') if the state's provision of the data to third parties is attached to a purpose limitation in accordance with the public task. Usually, this concerns the provision to selected parties (e.g. researchers, journalists or participants in a smart city network). The German 'Market Transparency Unit for Fuels' will be discussed later on as another illustrative example. ${ }^{95}$

An extension of this scenario is that the state passes on the datasets to everyone. This is the case when the accessed datasets fall under open data obligations. ${ }^{96}$ Technically, the mandated B2G data access would extend the data holdings of the state, which would then be available for wide re-use. An example is the French Loi Lemaire, which (at least in theory) also allows the state to make the data of concessionaries further available for re-use. ${ }^{97}$ Such unlimited re-use stands in evident conflict with the principle of purpose limitations. One could, however, frame 'open data' itself as a public task, e.g. by aiming to foster competition and innovation, economic welfare and transparency. ${ }^{98}$ Especially the transparency aspect appears manifold since the B2G data sharing debate itself has raised calls for transparency obligations according to which public authorities should disclose their data sources.

92 Geoffrey Delcroix, 'Smart Cities and Innovative Uses for Personal Data: Scenarios for Using Data to Restore the Balance between Public and Private Spheres', (2017) Special Issue 17 Field Actions Science Reports 75, $79<$ http://journals.open edition.org/factsreports/4489> accessed 31 August 2020.

93 See Früh (n. 9) 529.

94 This only considers the datasets accessed and not insights, otherwise the mere provision of information would fall under this scenario.

95 See section E.VI. below.

96 E.g. according to the rules of the PSI Directive (n. 25).

97 Art. L-3131-4 Code de la commande publique states that 'the licensing authority or a third party designated by it may freely extract and exploit all or part of such data and databases, in particular with a view to making them available for re-use free of charge or against payment'. In practice, this is highly contested.

98 See Recital 13 PSI Directive (n. 25). 


\section{Obliged parties (against whom?)}

Private companies, meaning commercial entities and not individuals, are to be defined as the obliged party (against whom?). There are different points of reference for further delineation. A common approach is to address the sector of the data holders, e.g. telecommunications operators, mobility providers, car manufacturers, retailers or social media providers. ${ }^{99}$ Another way is to refer to economic or rather functional characteristics, e.g. access to data of online platforms. ${ }^{100} \mathrm{~A}$ third possibility is to generally refer to 'holders' or 'creators' of the particular dataset needed. This is relevant when the desired insights can only be derived from combining datasets of different sources and a hold-up problem should be avoided. ${ }^{101}$ The effectiveness of such an output-centred definition then fully depends on the data to be defined.

\section{Relevant data (what?)}

In any case, it is necessary to specifically define the affected data (what?). The definition of data as the subject matter of access rules corresponds to the public purpose to be fulfilled. Various data taxonomies exist for classifying the processing degree of data in the information value chain. ${ }^{102}$ Among other things, access rules can address raw data, processed information or data-driven insights. ${ }^{103}$ The access rules must also determine the degree of granularity and update frequency (static or dynamic) of the data

99 For examples see European Commission Communication COM (2018) 232 final (n. 4) 12; Alemanno (n. 1) 183; Verhulst and Young (n. 33).

100 E.g. when referring to 'online platforms'; see European Commission Communication COM (2018) 232 final (n. 4) 12. See also Art.9 Regulation (EU) 2019/1150 of the European Parliament and the Council of 20 June 2019 on promoting fairness and transparency for business users of online intermediation services [2019] OJ L186/57 (P2B Regulation), which defines and regulates 'online intermediation services' and 'online search engines' and contains transparency obligations on the accessibility of their data.

101 See European Commission (n. 5) 21.

102 In general Kitchin (n. 11); Martens and Duch-Brown (n. 13) 17 distinguish between direct data delivery, indirect data trade (intermediate inputs) and databased services.

103 See also European Commission (n. 5) 22-23. For a legal definition of 'raw data' see Sec. 12a German Act on digital administration (Gesetz zur Förderung der elektronischen Verwaltung). 
and other quality parameters. ${ }^{104}$ At the same time, definitions explicitly exclude certain data in order to protect private or public interests or because it would simply be too costly to make them available and would therefore pose an undue burden on the companies. ${ }^{105}$ If personal data are at stake, data protection law applies and access rules must be designed in conformity with data protection regimes. The legislature has much less leeway as compared to access regimes which do not touch upon personal data.

Access rules can also address the issue of 'information about the data', which resembles Arrow's information paradox ${ }^{106}$ in a data-driven context: How does the state find out about the datasets that private undertakings actually hold? And how can the state assess whether access to these datasets effectively provides the desired insights? One way to tackle these challenges is to include disclosure/transparency obligations on companies with regard to the types of data they hold. In addition, access rules could mandate support of the businesses to assess the quality. ${ }^{107}$ Access rules can therefore be designed as a right that follows a three-step logic: 1 . access to information about the datasets, 2. access to (sample) datasets for assessing their usefulness with regard to the public purpose, 3 . access to datasets for using them in accordance with the purpose.

\section{Modalities of access (how?)}

Finally, the modalities (bow?) of data access must be defined. There is no clear delineation of what can be categorised as a modality, but it may help

104 See European Commission (n. 5) 73; European Commission Staff Working Document SWD(2018) 125 (n. 47) 14. For a legal definition of 'dynamic data' see Art. 2(8) PSI Directive (n. 25); for a sectoral approach to specify these parameters, see Commission Delegated Regulation (EU) 2017/1926 of 31 May 2017 supplementing Directive 2010/40/EU of the European Parliament and of the Council with regard to the provision of EU-wide multimodal travel information services [2017] OJ L272/1 (Multimodal Travel Information Regulation).

105 On the theoretical background Friedrich Schoch, Informationsfreiheitsgesetz $\left(2^{\text {nd }}\right.$ edn, C.H. Beck 2016) Vor $\$ \$ \$ 3-6$, regarding the rights of access to information of public authorities; furthermore Heiko Richter, Informationsweiterverwendungsgesetz (C.H. Beck 2018) $\$ 1$ paras 23-32.

106 Kenneth J. Arrow, 'Economic Welfare and the Allocation of Resources for Invention' in NBER (ed.), The Rate and Direction of Inventive Activity: Economic and Social Factors (Princeton University Press 1962) 609-26.

107 See European Commission Staff Working Document SWD(2018) 125 final (n. 47) 15. 
to think in terms of technical, economic and legal modalities. In general, all modalities need to serve the fulfilment of the purpose of mandated access.

Technical modalities relate to the technical infrastructure and solutions which enable data access. The regulator can base access rules on existing technical infrastructure or mandate the establishment of new infrastructure. ${ }^{108}$ In this regard, access means the transfer or exchange of data. Direct state access to private databases is usually ruled out for security reasons. Rather, the law obliges companies to transmit data (e.g. via API), share them via trusted intermediaries, put them into a data pool ${ }^{109}$ etc. Where suitable, it can be less intrusive or more effective to mandate the sharing of insights as compared to raw data. There are also technical solutions which allow the state to draw conclusions from data without having to transfer the data to it. ${ }^{110}$ Further technical modalities concern standards for data exchange ${ }^{111}$ and formats ${ }^{112}$ as well as the access duration. Such time limits can satisfy the principle of proportionality or data protection rules. ${ }^{113}$

An important and vividly discussed condition is compensation. ${ }^{114}$ Data access may incur significant costs and the regulator must decide who will bear them. ${ }^{115}$ Access rules that address compensation can be regarded as

108 See for examples of legislation which led to the establishment of new data infrastructure Directive 2007/2/EC of the European Parliament and the Council of 14 March 2007 establishing an Infrastructure for Spatial Information in the European Community (INSPIRE) [2007] OJ L108/1; Directive 2010/40/EU of the European Parliament and of the Council of 7 July 2010 on the framework for the deployment of Intelligent Transport Systems in the field of road transport and for interfaces with other modes of transport [2010] OJ L207/1.

109 See Martens and Duch-Brown (n. 13) 18; Shkabatur (n. 17) 362; for data pools in particular see Björn Lundqvist, 'Competition and Data Pools' (2018) Journal of European Consumer and Market Law 146.

110 See European Commission (n. 5) 62; Martens and Duch-Brown (n. 13) 18; see e.g. the OPAL project <www.opalproject.org/> accessed 31 August 2020.

111 See the recommendation of the European Commission (n. 5) 72 to invest in the development of common standards for data, metadata, representation and standardised transfer protocols.

112 For a legislative approach see Art. 5 PSI Directive (n. 25).

113 See Commission Staff Working Document SWD(2018) 125 final (n. 47) 15.

114 See European Commission (n. 5) 39; Commission Staff Working Document SWD(2018) 125 final (n. 47) 15.

115 See Cédric Villani, For a Meaningful Artificial Intelligence: Towards a French and European Strategy (2018) 28; Shkabatur (n. 17) 398. If companies carry the cost, one has to ask whether they can pass them on to the consumers and what the effect on demand is. 
'price regulation', which affects the private undertakings' incentives. ${ }^{116}$ Constitutional requirements may demand compensation, but usually the principle of proportionality gives some leeway for the regulator to decide whether to introduce compensation, ${ }^{117}$ so that it largely amounts to a policy decision. ${ }^{118}$ Yet the sui generis database right could mandate compensation. ${ }^{119}$ When it comes to determining compensation, different cost-based approaches exist: free of charge, marginal cost, full cost recovery or market price. ${ }^{120}$ In any case, charging provisions should not negatively affect the company's ability to collect/create the data ${ }^{121}$ or create negative incentives regarding the development of markets and competition. It is therefore important to understand that lower compensation may be necessary when accounting for market structure (monopolistic pricing for single source datasets), ${ }^{122}$ while higher compensation may be appropriate to ensure a suitable level of data quality. But benefit-based approaches are also discussed. The type and amount of compensation would then depend on the benefits associated with the use or purpose of mandated data access. Costbased compensation seems the more reasonable option from an economic standpoint because benefit-based compensation runs the risk of conflating distributional aspects and faces the general challenge of accurately estimating the benefits of data access for public purposes ex ante. ${ }^{123}$

Access rules should also address other legal issues in order to create legal certainty and system-wide trust. This concerns the handling of legally pro-

116 See Martens and Duch-Brown (n. 13) 13.

117 Under German law, this holds true as long as mandated access does not interfere with property positions protected by Art. 14 of the Basic Law (if there is intellectual property protection, the rationale of the judgment of the Federal Constitutional Court, 7 July 1971, Case 1 BvR 765/66 (1971) Neue Juristische Wochenschrift 2163 - Schulbuchprivileg applies; if there is no intellectual property protection, Federal Constitutional Court, 14 July 1981, Case 1 BvL 24/78 (1982) Neue Juristische Wochenschrift 633 - Pflichtexemplare becomes relevant).

118 According to Cytermann and others (n. 35) 3, there should be compensation in France if access goes beyond 'data of general interest with public link'.

119 See section G.III. below.

120 See European Commission (n. 5) 39. There is a significant body of literature about cost-based pricing of public sector information, see e.g. Marco Ricolfi and others, 'Principles governing charging for re-use of public sector information', (2011) XX/1-2 Informatica e diritto 105; Rufus Pollock, 'The Economics of Public Sector Information' (2008) University of Cambridge $<$ https://rufuspollock.co m/papers/economics_of_psi.pdf $>$ accessed 31 August 2020.

121 See European Commission Communication COM(2018) 232 final (n. 4) 13.

122 See Martens and Duch-Brown (n. 13) 13.

123 See on the quality of data as 'experience goods' European Commission (n. 5) 21. 
tected data (e.g. data protection, IP and trade secrets). The law should be clear on the interfaces. Furthermore, well-defined liability rules ${ }^{124}$ can clarify the risks and remedies. Another important yet underdeveloped issue is the relationship between mandated access and the voluntary conclusion of data-sharing contracts. Regulation ${ }^{125}$ should clearly address to what extent contracts between the state and private partners should take precedence over legal obligations. ${ }^{126}$ Mandatory rules do not necessarily exclude voluntary measures.

A general issue concerns preferential conditions for the public sector regarding data access in the context of mandatory access rules. ${ }^{127}$ This covers situations in which both the state and private actors can claim access, yet where the rules ensure better conditions for the state. Such preferential treatment can be reflected in lower prices, higher quality, earlier delivery etc. ${ }^{128}$ It is important to distinguish between different grounds for such preferential treatment. Reasons can be found in the benefits enjoyed by the public if the state obtains the data (e.g. due to high positive externalities the state can effectuate or the high importance or urgency of the task to be fulfilled), in justice considerations and in social values underpinning the perception that it is unfair if the community has to 'buy back data or data-based services from private individuals at considerable cost'. ${ }^{129}$ Preferential treatment can also be based on cost-related grounds and fiscal considerations. Regardless of the concrete motivation to include preferential treatment, such rules should always consider the effects on markets and potential distortions of competition.

124 See European Commission Staff Working Document SWD(2018) 125 final (n. 47) 16. The European Commission (n. 5) 26 identified the applicable liability regime as one of the major uncertainties to be tackled.

125 For a regulatory approach, see e.g. Art. 7(1) Directive (EU) 2019/790 of the European Parliament and of the Council of 17 April 2019 on copyright and related rights in the Digital Single Market and amending Directives 96/9/EC and 2001/29/EC [2019] OJ L130/92.

126 See Pailhès (n. 61) 5, arguing that contracts should override intervention.

127 Preferential conditions have so far only been considered in contractual arrangements, e.g. European Commission Communication $\operatorname{COM}(2018) 232$ final (n. 4) 13.

128 Ibid.

129 See Früh (n. 9) 525. 


\section{E. Principles for developing access rules}

\section{Function of principles}

The key questions above clarify what issues need to be addressed when formulating mandatory access rules and outline options for their design. However, they do not give any normative guidance on whether mandatory access rules should be introduced and according to which measures they should be developed. This section aims to give such normative guidance and develops four principles for designing access rules. These principles are based on economic theory, constitutional requirements and real-world observations. While the principles take the functioning of data-driven markets and innovation into particular consideration, they do not explicitly distinguish between horizontal and sectoral approaches. ${ }^{130}$ Moreover, they do not address the policy concern of setting priorities between different purposes and concrete areas for which mandatory access is considered desirable.

\section{Principle of justifying statehood}

According to the principle of justifying statehood, legitimate reasons must be provided if a mandatory access right for the state vis-à-vis private undertakings is to be established. This principle addresses the justification for intervention as such (' $i f$ ), while the remaining three principles concern the means of intervention ('bow'). ${ }^{131}$ The principle of justifying statehood has a legal and an economic/political dimension. While fundamental rights can require a justification for state intervention, economic and political considerations inform whether mandatory access actually makes sense.

When reflecting on the justification for state intervention, much depends on the perception of the role of the state. Here, this long-standing debate is reflected in data policies: What does the principle of subsidiarity mean in a data-driven economy? For determining the intervention threshold, a liberal view would consider economics-based theory, which frames

130 This will be addressed in section F. below.

131 If there is, however, no feasible way to design them, this can lead to the conclusion that there should be no intervention at all. 
justification for intervention on the grounds of market failure. ${ }^{132}$ Mandatory access rules would correct this failure and enhance the general welfare of society (which would thus deem them legitimate). ${ }^{133}$ However, the law (especially of the Member States) does not require market failure as a necessary condition for intervention. Instead, interventions on the basis of the public interest are legitimate as long as constitutional requirements - especially the purpose limitation and the principle of proportionality - are met.

The suggested principle of justifying statehood finds some middle ground. On the one hand, purely economic reasoning may not suffice, as it runs the risk of squeezing problems into the straightjacket of the market such that they cannot be adequately conceptualised. Also, such an emphasis raises methodological problems ${ }^{134}$ which throw its applicability into question and run the risk of overlooking the public interest and democratic will at large. On the other hand, mere public interest-based reasoning ${ }^{135}$ may be legitimate but not reasonable because it poses the risk of turning invocations of the 'common good' into a commonplace. Such a perspective fails to answer in which cases mandatory data access is reasonable and effective. It would also ignore the functional particularities of data as the concerned subject matter. Therefore, the following three characteristics of data access should be considered when justifying access rights for the state.

Firstly, the distinct feature of the state is its monopoly on the use of force. Mandatory access for the state would therefore require that only applying public force (meaning access against the will of the private undertaking) can guarantee that the data fulfil certain beneficial characteristics (e.g, completeness, punctuality and quality). Mandatory access rules can also address scenarios where reaching the goal is highly important or urgent, e.g. for the protection of public health. A conceptual problem is

132 See for this approach Martens and Duch-Brown (n. 13) 5; however, they (ibid. 12 , n. 10) acknowledge other reasons for intervention by referring to the Commission's better regulation toolbox: regulatory failure, equity concerns and behavioural bias. On the methodology of creating data ownership and access rights Heiko Richter and Reto M. Hilty, 'Die Hydra des Dateneigentums - eine methodische Betrachtung' in Stiftung Datenschutz (ed.), Dateneigentum und Datenhandel (Erich Schmidt Verlag 2018) 241, <https://papers.ssrn.com/sol3/pap ers.cfm?abstract_id=3263404> accessed 31 August 2020.

133 See Martens and Duch-Brown (n. 13) 12-20.

134 Ibid. 9.

135 This could almost blindly refer to the fulfilment of public tasks and the (presumed) will of the majority, as long as fundamental rights - which protect the will of the minority - are obeyed. 
whether the data must be an indispensable input for reaching the concrete purpose. ${ }^{136}$ The requirement of indispensability should be generally upheld, though there can be problems when applying it to cases that concern the 'mere improvement' of existing services or if the data are available on the market but at too high costs. These issues are well known in competition law (essential facilities doctrine), which can inform the further development of access rules in this regard. ${ }^{137}$

Secondly, the economic features of data - especially economies of scale and scope - may lead to centralisation advantages, which the state (and not private actors) might be able to effectuate for the benefit of all by harvesting insights based on private data sources. This can correspond to the matter of completeness, especially if market forces lead to hold-up problems. To a certain extent, one can draw the analogy of a state as a powerful data platform. However, the state is obviously subject to different logics of function and control than the private sector.

Thirdly, the extent to which the state is trusted more than private individuals is relevant. Trust not only strengthens incentives for voluntary cooperation; it may also increase the social acceptance of legal obligations. As stated above, B2G data access is framed by the debate of trust in democratic decision-making vs. trust in the functioning of markets. ${ }^{138}$ Depending on the political leadership, the public sector in particular may be regarded as a trustworthy partner, making companies more willing to provide data to it. ${ }^{139}$

\section{Principle of holistic rules}

According to the principle of holistic rules, it is elementary to consider the incentives of all actors who are involved or potentially affected. It requires an understanding of the relationship between causes and effects in their

136 See Früh (n. 9) 531.

137 See e.g. Inge Graef, EU Competition Law, Data Protection and Online Platforms: Data as Essential Facility (Wolters Kluwer 2016); Jacques Crémer, Yves-Alexandre Montjoye and Heike Schweitzer, 'Competition Policy for the digital era' (European Commission 2019) 98-107 < http://ec.europa.eu/competition/publications/r eports/kd0419345enn.pdf > accessed 31 August 2020; Thomas Tombal, 'Economic Dependence and Data Access' (2020) 51 International Review of Intellectual Property and Competition Law 70.

138 See section B. I. above.

139 See Shkabatur (n. 17) 393. 
entirety. By that means, the legislature can avoid the emergence of unintended side-effects (e.g. evoking new market failures through the introduction of dysfunctional rules). When designing mandatory access rules, it is therefore important to consider where the data come from (how did the private undertakings themselves get the data?) and what the state does with them (does the state further distribute the data to third parties or even to the public at large?). ${ }^{140}$

One should not overlook a natural tension which is inherent to the incentives of data sharing: on the one hand, the widest possible dissemination of data maximises the societal benefits; on the other hand, this opening up of data can reduce the willingness of a company to generate or collect data and to share them with the state. To take this a step further, it could reduce the willingness of third parties to provide data to the companies for their part if they know that the state will further distribute these data. ${ }^{141}$ The constitutional assessment echoes this ambiguity: on the one hand, the further dissemination of data by the state increases the benefits for the common good and may thus justify legislative intervention; on the other hand, such data dissemination can also intensify the intervention into constitutionally protected positions of the company. These opposing effects are to be taken into account when assessing the proportionality of legal intervention.

Regulation could address this 'opening dilemma' by providing selective disclosure. This means that the state would only pass on data to third parties who would not harm the incentives for the generation or sourcing of these data. Appropriate legal and technical arrangements can safeguard these interests. What can be seen is that rules on the re-use of data can impact the incentives to provide data and may therefore undermine the design of access rules. Legal clarity on re-use is therefore an important prerequisite for effective and legitimate rights of government access to privately held data.

140 See also Martens and Duch-Brown (n. 13) 13, who rightly emphasise that one must look at the upstream data market and downstream services markets as an integrated entity.

141 On this hypothesis regarding personalised law Elkin-Koren and Gal (n. 9) 41429. 


\section{Principle of responsibility}

When designing access rules, new rights correspond with new obligations. A state that accesses datasets of private undertakings must therefore be responsible to individuals, the undertaking and the public at large. Under this principle of responsibility, the state should protect private interests and safeguard the legitimate interests of companies. ${ }^{142}$ This claim is reflected in the constitutional principles of purpose-relatedness and proportionality of interventions. ${ }^{143}$ Mandatory access appears delicate, particularly regarding datasets that are critical for the competitiveness of the company and where their analysis by the state and disclosure to third persons could undermine the company's business model. ${ }^{144}$ There is also the more general concern that different degrees of openness may lead to distortions of competition. Conflicts of objectives must be identified and addressed. It is therefore important that access rules refer to the protection of business secrets, privacy and competition as such and clarify the relationship between them.

Looking at society at large, mandatory access for the state can create an informational advantage and therefore increase arcane knowledge. To hold the state accountable and trustworthy, transparency obligations ${ }^{145}$ should force the state to plausibly account for its access to and use of the privately held data.

\section{Principle of proximity}

Finally, the principle of proximity can inform the decision on where and how to introduce mandatory access rules. This principle acts as a rule of thumb which may increase the effectiveness of such access rules. The principle of proximity is very general - it means that thinking in terms of the proximity of relationships can be beneficial for the development of access rules. Close relationships may exist on many different grounds. For example, a legal obligation to provide information or transfer data between the state and the affected entities may already exist. Also, existing technical in-

142 See European Commission Communication $\operatorname{COM}(2018) 232$ final (n. 4) 13; European Commission (n. 5) 46.

143 However, the exact delineation with regard to property protection remains unsettled; see with regard to Art. 17 EU Charter of Fundamental Rights Fabian Michl (n. 83).

144 See Martens and Duch-Brown (n. 13) 21.

145 See European Commission (n. 5 ) 46. 
frastructure or know-how can constitute such proximity. Moreover, de facto close relationships can often be observed in the smart city context, where different actors share a common public space. To put it in other words: the proximity principle means that introducing mandatory access rules should follow a step-by-step approach with strategic foresight.

\section{Example: German 'Market Transparency Unit for Fuels'}

A successful example of a 'new regulatory approach'146 to mandatory access rules can illustrate these principles. In 2013, the 'Market Transparency Unit for Fuels' (MTS-K) was set up at the German competition authority Bundeskartellamt (BKartA). Its original purpose was to monitor fuel price formation and thereby facilitate the detection of cartel violations (principle of justifying statehood). ${ }^{147}$ To this end, a mandatory access law ${ }^{148}$ expanded the state's information base: it obliges all 14,500 petrol stations in Germany to report price changes for three types of fuel in real time to the BKartA. ${ }^{149}$ This obligation is subject to a fine and is without compensation. The BKartA evaluates these data. ${ }^{150}$ In addition, the law authorises the BKartA to pass on the real-time data to private consumer information services. To prevent abuse, these services need to register (principle of responsibility). Their 'fuel price apps' are intended to increase consumer sovereignty and to discipline the fuel market. Such apps existed before, but they were mostly based on user-generated data and were by far not as comprehensive, precise and up to date (principle of justifying statehood).

146 See also Matthias Knauff, 'Staatliche Benzinpreiskontrolle' (2012) Neue Juristische Wochenschrift 2408, 2412.

147 Bundesregierung, 'Entwurf eines Gesetzes zur Einrichtung einer Markttransparenzstelle für den Großhandel mit Strom und Gas' (21 June 2020) Bundestages-Drucksache 17/10060, 2 <https://dip21.bundestag.de/dip21/btd/17/100/1 710060.pdf $>$ accessed 31 August 2020.

148 More precisely, the model follows multi-level regulation: law, ordinance and general administrative ruling (which contains more detailed provisions on the technical design of data transmission).

149 Cf. Sec. 47k German Act against Restraints of Competition (GWB).

150 On the genesis see Bundesregierung, 'Bericht über die Ergebnisse der Arbeit der Markttransparenzstelle für Kraftstoffe und die hieraus gewonnenen Erfahrungen' (3 August 2018) Bundestags-Drucksache 19/3693, $3<$ https://archive.org/deta ils/ger-bt-drucksache-19-3693> accessed 31 August 2020. 
To a considerable extent, the success of the MTS-K can be explained by its reliance on existing technical infrastructure. ${ }^{151}$ It could therefore efficiently utilise already existing expertise and infrastructure (principle of proximity). Moreover, informing the consumer about the prices was deliberately left to private companies (principle of holistic rules) and thus to market forces. ${ }^{152}$ There are currently about 50 private providers, some of them with innovative business models. ${ }^{153}$ In fact, a market of service providers who have developed solutions for price reporting has also emerged. ${ }^{154}$

There is, however, a strict purpose limitation for re-using the data. The law only allows disclosure of the data to the Monopolies Commission and the Ministry of Economics (principle of holistic rules). ${ }^{155}$ So far, third parties do not have a right to access these data, even though there have been further requests. ${ }^{156}$ Yet in some cases the consumer information services have apparently passed on some data to third parties, which the MTS-K does not regard as objectionable as long as the data are used in accordance with the regulatory objectives. ${ }^{157}$ It is currently debated whether at least statistical offices should be given access upon request. ${ }^{158}$ In any case, the MTS-K has to regularly evaluate and report on the data collected and the effectiveness of the measure (principle of responsibility).

151 Costs could be significantly reduced by cooperating with the Bundesanstalt für Straßenwesen, where an IT system ('Mobilitäts Daten Marktplatz') already existed.

152 See Bundesregierung (n. 150) 25.

153 Ibid. 10.

154 Ibid. 7.

155 Sec. $47 \mathrm{k}(4)$ GWB.

156 See Bundesregierung (n. 150) 11-14, 24: all of them were rejected.

157 Ibid. 12.

158 See ibid. 24. However, see Gesetzentwurf der Bundesregierung - Entwurf eines Gesetzes zur Änderung des Gesetzes gegen Wettbewerbsbeschränkungen für ein fokussiertes, proaktives und digitales Wettbewerbsrecht 4.0 und anderer wettbewerbsrechtlicher Bestimmungen (GWB-Digitalisierungsgesetz) (9 September 2020) $15<$ www.bmwi.de/Redaktion/DE/Downloads/Gesetz/gesetzentwurf-gwbdigitalisierungsgesetz.pdf?_blob $=$ publicationFile $\& v=6>$ accessed 15 September 2020, which proposes to include an extension, according to which the MTS-K 'can also pass on location information, aggregated or older data to other authorities and offices of the direct federal and state administration for their legal tasks, but quantity data must always be highly aggregated'. 


\section{F. Towards a horizontal B2G access framework?}

\section{Overview}

As outlined above, ${ }^{159}$ this analysis has focused on overarching regulatory aspects without addressing sector-specific peculiarities. Yet the chapter has reflected on substantive common denominators by raising key questions and developing general principles which could inform the development of both sector-specific rules and horizontal rules. However, questions remain as to whether a horizontal access framework can indeed be beneficial and what its regulatory focus could be. This section explores whether and how legislatures should introduce a horizontal B2G data access framework. It focuses on mandatory rules; voluntary guidelines are not discussed. ${ }^{160}$

The policy debate on introducing a mandatory horizontal framework is just beginning. One can observe a certain reluctance because B2G data access is a sensitive issue. Even in France, where a horizontal framework has been considered since early on, such a general legal regime for 'data of general interest' was held to be 'neither desirable nor legally possible', taking the diversity of the sectors and data concerned into account. ${ }^{161}$ Rather, a sectoral, case-by-case approach was recommended and followed. ${ }^{162}$ However, the European Commission explicitly inquired into the need for a horizontal approach, and the $\mathrm{B} 2 \mathrm{G}$ expert group has reinforced this concern by recommending the Commission to further 'explore the creation of an EU regulatory framework to enable and facilitate B2G data sharing for public interest purposes'. ${ }^{163}$ The expert group considers mandatory rules, as it addresses cases in which 'private companies would be required to share the necessary data' and argues for obligations with regard to data that are scarce, unique, needed to ensure compliance or part of cross-border datasets. ${ }^{164}$ Compared to the Member States, however, the Commission has a slightly different perspective that emphasises the internal market. The need for and potential design of a horizontal framework therefore depends on its supposed purpose.

159 See section C.IV. above.

160 See on the activity already (n. 47).

161 See Cytermann and others (n. 35) 2.

162 See Villani (n. 115) 28.

163 See European Commission (n. 5) 41.

164 Ibid. 43. 


\section{Purpose of a horizontal framework}

Whether it is sensible to introduce mandatory horizontal rules on B2G data sharing and how to design such rules depends on the purpose of choosing a horizontal approach. A horizontal framework should amount to more than just a common denominator of sectoral rules - it should offer some additional advantages that stem from its horizontal nature. One should therefore be cautious about pleading for simply turning existing non-binding $\mathrm{B} 2 \mathrm{G}$ access principles ${ }^{165}$ into mandatory law without clarifying the actual purpose and extra benefit of introducing horizontal mandatory rules.

The European Commission sees the benefits of an EU-wide framework in the potential for cross-border harmonisation to ensure a consistent approach between the Member States and to decrease fragmentation. ${ }^{166}$ However, one can argue that increasing coherency is a means rather than an end in itself. Given the different concepts and preferences for defining public interest, there is also no doubt that frameworks must provide a certain flexibility for the Member States, ${ }^{167}$ a major issue being the scope of application: French law could not authorise French authorities to claim access to data of companies in Spain, even if the datasets could be of use for the French authorities. Only overarching, EU-wide rules could reasonably address such issues, but it remains doubtful whether the EU's competence reaches this far. The EU must either base its laws on special designated policy competences or on the general internal market competence. ${ }^{168}$ To justify the latter, economic and market reasoning shift to the centre of attention.

Another purpose of a horizontal framework is cross-sectoral harmonisation. A minimum level of harmonisation could lead to more consistency in the development of sectoral rules and prevent fragmentation between sectors. ${ }^{169}$ Again, consistency in itself seems rather a means than an end. It would be desirable for cross-sectoral harmonisation to serve substantive forms of improvement, such as decreased costs and higher efficiencies for B2G data sharing or more legal certainty. Cross-sectoral harmonisation

165 See n. 47.

166 See European Commission (n. 5) 36, also identifying an 'uncoordinated approach'.

167 Ibid. 41.

168 See for a debate of the scope of the internal market competence Annegret Engel, The Choice of Legal Basis for Acts of the European Union (Springer 2018) 20-27.

169 See European Commission (n. 5) 36, 41. 
could also effectuate synergies, e.g. regarding the findability of the data needed.

Ultimately, a binding horizontal framework can serve the achievement of substantive goals. These goals are reflected in the substantive issues the framework would address (e.g. pricing, formats etc.). Therefore, the key question concerns which additional benefits a codification of horizontal obligations would provide. One can distinguish between market-related and non-market-related goals. Thus, substantive rules need to be tested against the question of why their horizontally binding quality would improve the status quo. While possible substantive issues will be further discussed in detail below, ${ }^{170}$ some general characteristics of a potential horizontal framework are examined in the following.

\section{Possible functions of a horizontal framework}

Which functions can a horizontal B2G data access framework perform? Depending on its purpose, such a framework can fulfil different functions which are reflected in its design.

First, the framework can fulfil an enabling function. This means that it provides a minimum standard of rules, which should enable Member States to 'make data sharing mandatory for purposes that are particularly relevant to their national or local priorities'. ${ }^{171}$ However, it is already the case that the Member States can themselves introduce mandatory rules on sharing if they prefer to. The above-mentioned cross-border cases are an exception. Also, enabling frameworks appear relevant for EU sectoral policies and for the Member States themselves with regard to any national access rules. The enabling function of frameworks is also relevant in terms of the hierarchy of rules. In practice, access regimes often stretch over several regulatory levels. Especially technical details are mostly found in sub-legal regulations. ${ }^{172}$

170 See section F.IV. below.

171 European Commission (n. 5) 44.

172 See INSPIRE Directive and ITS Directive for examples, where details are addressed in delegated acts and implementing decisions. The same applies to financial data (see Directive (EU) 2015/2366 of the European Parliament and of the Council of 25 November 2015 on payment services in the internal market [2015] OJ L337/35) and vehicle repair information (see Directive (EC) 715/2007 of the European Parliament and of the Council of 20 June 2007 on type approval of motor vehicles with respect to emissions from light passenger and commercial 
Second, a horizontal framework could harmonise procedures rather than substance. For example, France discussed drawing up a common framework which included procedural rules that were not meant to be necessarily binding for the sectors. ${ }^{173}$ One could also think about setting up binding procedures to ensure transparency and broad engagement for the further development of rules. This is particularly relevant for procedures which define the public interest and designate the respective purposes and datasets.

Third, a horizontal framework could address interfaces with other legal regimes. Alternatively, the legislature could amend other horizontal regimes by systematically including or modifying rules on $\mathrm{B} 2 \mathrm{G}$ data sharing. For example, competition law could include indemnity or safe harbour ${ }^{174}$ provisions for violations without creating generic access rights. Furthermore, the platform regulation ${ }^{175}$ could accommodate respective issues of B2G data sharing.

Fourth, an important function of an EU horizontal framework lies in the provision of default rules from which Member States can deviate. Actually, such optional regulation is inherent to any EU rules that pose minimum and not full harmonisation. ${ }^{176}$ Rather, default rules can provide 'harmonised flexibility' by specifying a bundle of concrete regulatory options. ${ }^{177}$ If Member States must 'opt in' to these rules, the rules serve mere standardisation purposes and can provide legal certainty and lower transaction costs. 'Opt out' rules may provide additional benefits because they could - depending on the procedure ${ }^{178}$ - pressure Member States to justify their deviation from the default. Should the horizontal framework require

vehicles (Euro 5 and Euro 6) and on access to vehicle repair and maintenance information [2007] OJ L171/1).

173 See Cytermann and others (n. 35) 3.

174 See Früh (n. 9) 528.

175 See already the EU P2B Regulation (n. 100); see also Communication from the Commission of 19 February 2020 to the European Parliament, the Council, the European Economic and Social Committee and the Committee of the Regions Shaping Europe's digital future (Communication) COM (2020) 67 final, 10 on plans for a 'Digital Services Act' to address large platforms with ex ante regulation.

176 See e.g. Art. 1 PSI Directive (n. 25), according to which the 'Directive establishes a set of minimum rules'.

177 See Art. 4 Multimodal Travel Information Regulation (n. 104), which mandates access to static travel and traffic data, while Art. 5 standardises modalities only ' $[\mathrm{w}]$ here the Member States decide to provide the dynamic travel and traffic data'.

178 One could consider a 'comply or explain' mechanism. 
that substantive requirements must be met for opting out, such rules can be mandatory in effect. In any case, a horizontal framework would have to clearly name the criteria and procedures according to which Member States can exercise the provided options. Such 'harmonised flexibility' can also concern the (co-)existence of sector-specific measures. Depending on which substantive issues the horizontal framework addresses, it would also need to explicitly clarify its relationship to sector-specific regimes. ${ }^{179}$

\section{Substantive issues for a horizontal framework}

When it comes to substantive matters that a horizontal framework could address, one can think of the horizontal commonalities of all sectors and overarching issues. ${ }^{180}$ Considering the legislative competence of the EU, a meta question is how these issues relate to the internal market. Not all issues can be directly framed as a market problem, but a wider perspective can include consequences for competition, at least if the framework addresses its core parameters (like price and quality).

One substantive issue that a horizontal framework could address concerns the point of reference for defining the accessible data. ${ }^{181}$ Here, the horizontal framework would not address datasets regarding their particular information content but would outline rather general criteria as reference points for defining the data which are subject to mandatory access. The regulatory approach can follow three different, more abstract rationales. First, the framework could specify ways of determining and defining the public interest that would justify access. ${ }^{182}$ Obviously, 'social benefit' would provide an overly broad category that would call for refinement. An example is the recast PSI Directive, which outlines more concrete criteria to assess 'high-value datasets'. ${ }^{183}$ The framework could specify measures for assessment, e.g. the likelihood and amount of benefits and costs, the urgency, the harm of not using the data and other possibilities of accessing

179 Particularly to eliminate any ambiguity about the relationships of lex specialis and lex posterior.

180 See Cytermann and others (n. 35) 3.

181 This implies that datasets themselves are not enumerated, which could then be done in delegated or implementing acts of the EU or left to the Member States.

182 See European Commission (n. 5) 44, mentioning relevant criteria for assessing whether data sharing should be required for a given use case.

183 See Arts 13-16 PSI Directive (n. 25). 
the needed data. ${ }^{184}$ Second, the framework could refer to the competitive relevance for defining the data concerned. This approach would emphasise the bottleneck function of particular datasets (single-source data). One would have to further define requirements for access to such data, e.g. whether their indispensability is decisive. Much can be borrowed from competition analysis. ${ }^{185}$ Third, horizontal reference points can be of a rather technical nature. This is the case if the framework addresses data that are 'stored in databases' 186 or if it refers to the modalities of their creation (e.g. when collection takes place in public space or when using state infrastructure $\left.{ }^{187}\right)$.

Another major issue that horizontal rules could address is compensation (i.e. pricing). ${ }^{188}$ Horizontal rules can set out under which circumstances no compensation is required. In any case, they must take the incentives of the private undertakings into account. The framework could also outline pricing standards, means of calculating cost and transparency rules. Making a choice between the concrete available approaches to compensation (as mentioned above $)^{189}$ depends on the goals and the balancing of interests: competition-oriented approaches will take the market structure into account and address the problem of excessive (monopoly) pricing. ${ }^{190}$ At the same time, the benefits of introducing a marginal cost principle can lie in imposing a duty to justify pricing in general and to bring pricing practices under legal scrutiny before the courts. An additional issue is price discrimination, which a horizontal framework could address through a general provision that undertakings must grant access to the state on preferential conditions. ${ }^{191}$

The horizontal framework can address further issues, such as formats, technical issues and findability (i.e. 'information about the information'192). Furthermore, a horizontal framework can be used to absorb negative consequences, e.g. by harmonising liability rules which address the risk of reducing incentives to collect data, which can lead to an undersup-

184 See European Commission (n. 5) 44.

185 See n. 137.

186 Under the meaning of Directive 96/9/EC of the European Parliament and of the Council of 11 March 1996 on the legal protection of databases [1996] OJ L77/20.

187 See Früh (n. 9) 526.

188 See the focus of Martens and Duch-Brown (n. 13) 12-16.

189 See section D.VI.

190 See Martens and Duch-Brown (n. 13) 13.

191 See European Commission (n. 5 ) 39.

192 This resembles Art. 9 PSI Directive (n. 25) on practical arrangements which aim to improve findability of the information. 
ply. ${ }^{193}$ The horizontal framework could also clarify the relationship between statutory access rules and contracts. In fact, studies have revealed that some markets for B2G data sharing are about to evolve. ${ }^{194}$ When following a strict principle of subsidiarity, the horizontal framework could even reverse the logic and define in which cases access to datasets may not be mandated.

\section{PSI Directive as a model?}

The potential need for EU-wide horizontal rules that address B2G sharing calls to mind the PSI Directive. Can the PSI Directive serve as a model for designing horizontal B2G access rules? ${ }^{395}$ The PSI Directive of 2003, amended in 2013 and recast in 2019, ${ }^{196}$ was the first horizontal framework that regulated data re-use. Based on the notion that everyone should benefit from collectively financed goods, ${ }^{197}$ the Directive regulates the re-use of public sector information (e.g. weather data, registries, court decisions etc.). ${ }^{198}$ The Directive aims to stimulate the development of digital innovation and to foster transparency. ${ }^{199}$ At the same time, it seeks to prevent the distortion of competition in the internal market. ${ }^{200}$ For this purpose, the PSI Directive contains rules (e.g. on charging, formats, conditions and exclusivity) that apply to the re-use of information of public sector bodies

193 See Früh (n. 9) 525.

194 See Martens and Duch-Brown (n. 13) 10-11.

195 This question is different from the issue of whether the PSI Directive applies to data that originally came into the domain of the state via the B2G access right (see principle of holistic rules, section E.III. above).

196 After its recast, the PSI Directive is often also referred to as 'Open Data Directive'.

197 While some of their creation is financed by fees or charges, most of them are taxfunded.

198 The recast of 2019 includes public undertakings within the scope of the PSI Directive; see in detail Heiko Richter, 'Exposing the public interest dimension of the digital single market: Public undertakings as a model for regulating data sharing' (2020) Max Planck Institute for Innovation and Competition Research Paper No. 20-03 <https://papers.ssrn.com/sol3/papers.cfm?abstract_id=3565762> accessed 31 August 2020.

199 See Recital 3, 13 PSI Directive (n. 25).

200 See Recital 7 PSI Directive (n. 25). On this issue, see Björn Lundqvist, 'Turning Government Data Into Gold: The Interface Between EU Competition Law and the Public Sector Information Directive' (2013) 44 International Review of Intellectual Property and Competition Law 79. 
across the board. It provides a minimum level of harmonisation: national, re-use-friendlier rules prevail. ${ }^{201}$

However, framing the issue of B2G government access as 'PSI in reverse' appears misleading and should be avoided because there are major functional and conceptual differences between the subject matter of the PSI Directive and the challenges facing B2G data access. The PSI Directive concerns individual rights against the state, while B2G data access refers to the opposite situation of the state claiming access against private undertakings. From a legal point of view, many more restrictions apply due to the impairment of fundamental rights. This is reflected in the significance of purpose limitation, which is a seminal principle and a starting point for the constitutionality of B2G data access. In contrast, the PSI Directive aims at the opposite goal of unrestricted re-use of data. ${ }^{202}$ Moreover, the PSI Directive follows competition reasoning and aims to foster the development of markets, which justifies its reliance on the internal market competence. Finally (and related to the issue of legislative competence ${ }^{203}$ ), the PSI Directive only regulates re-use of, not access to data. In contrast, the discussion about B2G data sharing concerns mandatory access rights and the corresponding regulatory design. Given all these differences, the PSI Directive cannot serve as a blueprint for an EU-wide mandatory framework for B2G data sharing.

This does not imply, however, that the PSI Directive lacks any informative value. In fact, the Directive can serve as inspiration for the design of rules, as it contains established definitions e.g. on the bodies concerned and on formats. ${ }^{204}$ Especially with regard to pricing, the PSI has a well-refined set of rules, the product of long-standing discussions on different pricing models. ${ }^{205}$ This can inform B2G access as well. ${ }^{206}$ Yet one has to acknowledge the diverging rationale on which the pricing rules of the PSI Directive are based. Either they presume tax-financed information or -

201 E.g. lower charges and less restrictive licensing terms; see Recital 18 PSI Directive (n. 25).

202 This reflects the very idea of 'open data', which is echoed in Arts 3, 8 PSI Directive (n. 25): purpose limitations are deemed restrictions of re-use which need justification.

203 In detail Richter (n. 198).

204 E.g. public sector bodies according to Art.2(1) and formats according to Art. 2(13), (14), (15) PSI Directive (n. 25).

205 See Art. 6 PSI Directive (n. 25).

206 Especially when it comes to pricing regulation, Martens and Duch-Brown (n. 13) 14 draw analogies to the PSI Directive; see also European Commission (n. 5) 39, which refers to the pricing models of the PSI Directive. 
even if they allow for full cost-recovery - refer to the financing of the public sector body from a purely fiscal perspective, but do not account for the incentives to create the information. ${ }^{207}$ In contrast, pricing rules for $\mathrm{B} 2 \mathrm{G}$ access must take the incentives of private actors to innovate into account. Therefore, one should be careful about transplanting PSI rules on charging into the B2G data access context without thorough reflection.

An innovative part of the recast PSI Directive of 2019 concerns the special rules on high-value datasets. ${ }^{208}$ The model character of the procedure and the general criteria according to which datasets and sharing conditions are to be determined were already highlighted above. ${ }^{209}$ Another important implication of the PSI Directive's focus on re-use relates to the potential chilling effects of access rights. This means that overly strict re-use rules (i.e. a standardisation regime) can hamper data access if the entities which hold the data or the national legislature can choose whether to submit particular information to this horizontal standardisation regime. ${ }^{210}$ The legislature must consider this lesson if it intends to standardise only the conditions for B2G data without mandating access as such. Finally, the PSI Directive points to the relevance of the intersection with database law, ${ }^{211}$ an important interface that runs the risk of being overlooked. This, among other things, will be further discussed in the following.

\section{Conclusion}

In conclusion, this analysis abstains from making a concrete proposal for EU-wide mandatory B2G access regulation. It rather points to the challenge of concisely identifying the purpose of horizontal mandatory frameworks while emphasising the functions of such frameworks and how to shape the rules appropriately. The analysis has highlighted the difficulties and challenges that face the concrete design of legitimate and effective hor-

207 Recital 36 PSI Directive (n. 25) justifies the exemptions with 'the necessity of not hindering the normal running of public sector bodies'.

208 See Arts 13-16 PSI Directive (n. 25).

209 See sections D.V. and D.VI. above.

210 Further discussed in Richter (n. 198).

211 See Art. 1(6) PSI Directive (n. 25). For background see Estelle Derclaye, 'Does the Directive on the Re-use of Public Sector Information affect the State's database sui generis right?' in Jens Gaster, Erich Schweighofer and Peter Sint (eds), Knowledge rights - Legal, societal and related technological aspects (Österreichische Computer Gesellschaft 2008) 137. 
izontal rules. While the PSI Directive cannot serve as a blueprint, it does offer some lessons. Its implications not only concern EU-wide regulation but can also inform national horizontal B2G access rules, which the Member States themselves are free to introduce in future.

\section{G. Recommendations for concrete reforms}

\section{Reaching beyond access rules}

In the following, some recommendations for concrete legislative reforms are made which concern government access to the data of private undertakings. These recommendations reach beyond the concrete design of access rules. Rather, they address existing legal regimes which are seen as crucial in further developing mandatory access rules. By addressing them, legislatures can set the course for an effective implementation of access rules in future - whether of a horizontal or sector-specific nature.

\section{Reform laws on official statistics}

Reforms regarding government access to data are desirable in official statistics laws. Statistical obligations concern the transfer of information to the state by their very nature, and there is a long-standing tradition for such obligations in the Member States. Statistical offices appear well positioned to implement new forms of data access and can serve as a model: they already have infrastructure and high competence in data analysis and are particularly experienced in handling personal data. In addition, statistical offices are experienced in further distributing information and can therefore be seen as 'key information providers' 212 in a big-data world. The policy discussion regarding access to new data sources for statistical offices has advanced further than in other domains. ${ }^{213}$ In future, this area may be perceived and developed as an 'experimental ground' for B2G data access.

What are the relevant areas of application? One can think of a wide range, e.g. statistics on population movements, price development, the in-

212 Peter Struijs, Barteld Braaksma and Piet J.H. Daas, 'Official statistics and Big Data' (2014) 1(1) Big Data \& Society 1; on trust in statistical offices Shkabatur (n. 17) 394.

213 See European Commission Communication COM (2018) 232 final 12 (n. 4) 14. 
ternet economy, energy, transport etc. The creation of such statistics can be enabled and improved by access to privately held data sources, e.g. to mobile phone data, satellite images, social media data, cash register scanners, traffic sensors and smart electricity meters. ${ }^{214}$ Expectations for the social benefits are high ${ }^{215}$ because access to privately held data promises to foster efficiency. It can reduce costs for the statistical offices - e.g. if they can use data from telecommunications providers to quantify commuter movements instead of conducting complex individual surveys. ${ }^{216}$ It can also reduce costs on the side of businesses - e.g. when fulfilling their reporting obligations. ${ }^{217}$ Moreover, data access can improve the generic quality of official statistics - e.g. through quicker delivery, up-to-dateness, higher reliability, data quality and granularity and through gathering new insights when combining new datasets with administrative data. ${ }^{218}$

About a decade ago, a discussion developed on voluntary cooperation between statistical offices and private data providers. ${ }^{219}$ Yet the authorities

214 For examples see UN Statistics Division, 'Supplementing the United Nations Fundamental Principles of Official Statistics: Implementation Guidelines' (Background Document of 5-8 March 2019) <https://unstats.un.org/unsd/statcom/50t h-session/documents/BG-Item3b-FPOS-Implementation-guidelines-E.pdf> accessed 31 August 2020, 22-25; Lara Wiengarten and Markus Zwick, 'Neue digitale Daten in der amtlichen Statistik' (2017) 5 WISTA 19, 26; Bund-Länder-Arbeitsgruppe zur Reduzierung von Statistikpflichten, 'Abschlussbericht der ressortübergreifenden Bund-Länder-Arbeitsgruppe zur Reduzierung von Statistikpflichten' (2019) 16 <www.bmwi.de/Redaktion/DE/Downloads/A/abschlussb ericht-reduzierung-von-statistikpflichten.html > accessed 31 August 2020.

215 UN Statistics Division (n. 214) 18.

216 See Statistisches Bundesamt, 'Digitale Agenda des Statistischen Bundesamts' (Destatis 2019) $16<$ www.destatis.de/DE/Service/OpenData/Publikationen/digital e-agenda.pdf?_blob=publicationFile $>$ accessed 31 August 2020; on questionnaires see European Commission Communication COM (2018) 232 final (n. 4) 12.

217 See European Commission Communication $\operatorname{COM}(2017) 9$ final (n. 45) 14; Statistischer Beirat, 'Fortentwicklung der amtlichen Statistik: Empfehlungen des Statistischen Beirats für die Jahre 2018 bis 2022' (Destatis 2018) $9<$ www.destatis. de/DE/Ueber-uns/Leitung-Organisation/Statistischer-Beirat/fortentwicklung-nov2018-2022-teil3.pdf $>$ accessed 30 April 2020.

218 Statistischer Beirat (n. 217) 9-10; National Academies of Sciences, Engineering, and Medicine, Innovations in Federal Statistics: Combining Data Sources While Protecting Privacy (The National Academies Press 2017) 64; Wiengarten and Zwick (n. 214) 27; Früh (n. 9) 526; European Commission Communication COM (2018) 232 final (n. 4) 12.

219 On the background UN Statistics Division (n. 214); Wiengarten and Zwick (n. 214) 22; Struijs, Braaksma and Daas (n. 212) 3-4; on different forms of cooperation National Academies of Sciences, Engineering, and Medicine (n. 218) 65-66. 
lacked a legal basis for mandatory access. ${ }^{220}$ Therefore, the trend towards legal standardisation of access rights does not come as a surprise. ${ }^{221}$ In 2016, France enacted a general clause allowing access for the government. ${ }^{222}$ Details must be regulated on the basis of a decision by the minister, a consultation of the National Council for Statistical Information and a feasibility study. ${ }^{223}$ One year later, the UK enacted a law which authorises statistical offices to instruct private companies to submit data for statistical purposes. ${ }^{224}$ In contrast, such developments are largely on hold in Germany, ${ }^{225}$ where so far only price statistics have been addressed by new rules on access to scanner data from supermarket checkouts. ${ }^{226}$

In future, more legislation can be expected. Yet policymakers and legislators face some challenges, for instance in providing high quality and accurateness of statistical data while protecting private interests, namely personal data and business secrets. ${ }^{227}$ Another issue is compensation for the associated costs for private businesses. Traditionally, statistics laws do not grant compensation - the French and U.K. legislation are in line with that. Finally, the laws on statistics could also be revised to introduce provisions through which statistical offices could further share the data provided to them (e.g. with the scientific community). ${ }^{228}$

220 See UN Statistics Division (n. 214) 18.

221 For a plea see European Statistical System, 'Position paper on privately held data which are of public interest' (European Commission 2017) <https:/ec.europa.eu /eurostat/documents/7330775/8463599/ESS+Position+Paper+on+Access+to+priva tely+held+data+final+-+Nov+2017.pdf $>$ accessed 31 August 2020.

222 See Art. 19 of LOI n 2016-1321 pour une République numérique of 7 October 2016.

223 Ibid.

224 See Sec. 80 Digital Economy Act (2017), which modified Sec. 45D Statistics and Registration Service Act 2007.

225 See Statistisches Bundesamt (n. 216) 24 point B10.

226 See Act amending the Act on price statistics of 10 December 2019, Art. 1, Nos 78. See also Früh (n. 9) 528 on similar projects in France, Italy, the Netherlands and Poland. See for the harmonisation on the EU level Parliament and Council Regulation (EU) 2016/792 of 11 May 2016 on harmonised indices of consumer prices and the house price index, and repealing Council Regulation (EC) No 2494/95 [2016] OJ L135/11.

227 See UN Statistics Division (n. 214) 18; National Academies of Sciences, Engineering, and Medicine (n. 218) 67; Statistischer Beirat (n. 217) 10.

228 See Statistischer Beirat (n. 217) 11. 


\section{Modify database protection}

The sui generis protection for databases (Articles 7-11 Directive 96/9/EC) may set an - often overlooked - barrier to the future introduction and design of B2G access rules. ${ }^{229}$ It is unclear which (technical) forms of data access affect database protection and what the scope of protection is. ${ }^{230}$ Therefore, it appears likely that companies that own databases will claim more protection if the state gets mandatory access but does not provide compensation. ${ }^{231}$ Even if national legislatures want to provide compensation (e.g. by including respective provisions on compulsory licensing in an access law), there are good reasons to argue that the Database Directive does not allow this, because its exhaustive list of limitations does not cover this case. Especially the limitations for 'public security or for the purposes of an administrative or judicial procedure ${ }^{\prime 232}$ often do not help the state in this respect.

In fact, compensation is an issue that the access rules themselves should cover. ${ }^{233}$ To enable this, the EU legislature should introduce an opening clause into the EU Database Directive according to which special access rules of the Member States could take precedence over database protection. ${ }^{234}$ Otherwise, due to its major uncertainties, the sui generis database right runs the risk of blocking mandatory rules on government access to the data held by private undertakings.

229 See general remarks in Cytermann and others (n. 35) 74-75.

230 This concerns definitions, the threshold for substantiality, protected investments etc.; see Josef Drexl, 'Data Access and Control in the Era of Connected Devices Study on behalf of BEUC' (BEUC 2018) 67-85 <www.beuc.eu/publications/beuc -x-2018-121_data_access_and_control_in_the_area_of_connected_devices.pdf $>$ accessed 31 August 2020; Matthias Leistner, 'Big Data and the EU Database Directive 96/9/EC: Current Law and Potential for Reform' in Sebastian Lohsse, Reiner Schulze and Dirk Staudenmayer (eds), Trading Data in the Digital Economy (Hart and Nomos 2017) 27. See also European Commission Staff Working Document, 'Evaluation report of the European Commission on the Database Directive 96/9/EC of 25 April 2018' SWD(2018) 147 final.

231 In general Drexl (n. 230) 82, but not referring to the state in particular.

232 See Art. 9(c) Database Directive (n. 186).

233 Drexl (n. 230) 82.

234 See in general Drexl (n. 230) 83. 


\section{Coordinate advancement of re-use law}

The principle of holistic rules has highlighted the significance of the relationship between B2G access rules and rules on data re-use. In many instances, fundamental rights prevent the state from further disseminating the data for re-use. However, in other cases wide re-use is legitimate and welfare-enhancing. In order to provide legal certainty and regulatory effectiveness, the interface between access and re-use regimes must therefore be clearly defined. ${ }^{235}$ For this purpose, re-use regulation could be further developed in a forward-looking manner and made compatible with data access regimes.

In particular, re-use rules (i.e. the PSI Directive and respective national implementing acts) could regulate 'standard scenarios' which address different degrees of re-usability. Access regimes - whether on the EU level or national - could then explicitly refer to the adequate re-use scenario. Such reforms can currently be observed in Australia, ${ }^{236}$ where a legislative proposal distinguishes between three scenarios: 'closed data', 'shared data' and 'open data release'. ${ }^{237}$ Moreover, the proposal diligently combines procedures and technical infrastructure. Such an approach could be further refined and adapted in the frame of the next reform of the PSI Directive. ${ }^{238}$

\section{$V$. Strengthen subjective access rights}

Finally, one should keep in mind that B2G data access concerns a politically highly sensitive area. It can never be ruled out that the state will misuse data to wield its power over society. New technical possibilities enable selective (i.e. manipulative) data provision practices by the state. ${ }^{239}$ Access

235 Further discussed in Richter (n. 198).

236 See on the current project the discussion paper of the Australian Government, 'Data Sharing and Release - Legislative Reforms' (Data Commissioner 2019) $<$ www.datacommissioner.gov.au/sites/default/files/2019-09/Data\%20Sharing\%20 and\%20Release\%20Legislative\%20Reforms\%20Discussion\%20Paper\%20-\%20Ac cessibility.pdf $>$ accessed 31 August 2020.

237 Ibid. 3.

238 According to Art. 18 PSI Directive (n. 25), the Commission shall carry out its evaluation not sooner than 17 July 2025.

239 See Heiko Richter, 'Informationen der öffentlichen Hand als Rohstoff für den Datenjournalismus: Rechtliche Gestaltungsprinzipien zum Erhalt der Meinungsvielfalt' (2019) 83 UFITA - Archiv für Medienrecht und Medienwissenschaft 196. 
rules in favour of the state generally expand its data stock, but it is always uncertain who is going to rule over them in future. Therefore, it is paramount to equally empower society as a counterbalance. This can be achieved by strengthening citizens' subjective rights to access information of the state. ${ }^{240}$ This is the aim of the Tromsø Convention, ${ }^{241}$ which should therefore be signed, ratified and implemented in all Member States. The significance of freedom of information acts may have been stressed early on, ${ }^{242}$ but in view of the advancement of technical and societal development, this claim takes on much greater significance nowadays.

\section{H. Outlook}

This chapter has pointed out that a systematic establishment of rights for government access to the data of private companies is still in its infancy. It gives guidance on how to deepen the discussion and design regulatory concepts. While the further development of access rules will mainly take place on a sectoral basis, horizontal frameworks may provide benefits if they are conceptualised and designed thoroughly. This chapter makes suggestions for concrete reforms. It discusses how a targeted and coherent bundle of measures taken by the EU and its Member States can ensure that laws and policies on data access will effectuate and combine the common good and the development of individual freedom in the best way possible.

This chapter's introduction stated that the data access debate lies at the core of a general discussion on the state's role in a data-based society. When looking at further initiatives, one should therefore keep in mind that EU policies on B2G data access affect much more than just data flows across the internal market. They rebalance public and private powers. For this very reason, the state must not neglect its active role in protecting the functional conditions for a democratic society under the rule of law.

240 On the significance of subjective rights, see ibid. 214 (n. 116 with further references), 223.

241 Council of Europe Convention on Access to Official Documents of 18 June 2009, Tromsø, Council of Europe Treaty Series (CETS), No. 205.

242 For background see Dacian C. Dragos, Polonca Kovač and Albert T. Marseille (eds), The Laws of Transparency in Action (Palgrave Macmillan 2019); on initiatives in Germany Schoch (n. 105) Einleitung paras 295-97. 